\title{
Feasibility Study of Establishing a PV Power Plant to Generate Electricity in Saudi Arabia from Technical, Geographical, and Economical Viewpoints
}

\author{
E. Al-Ammar ${ }^{1,2}$, A. Al-Aotabi ${ }^{3}$ \\ ${ }^{1}$ Sustainable Energy Technology Innovation Program (SETIP) \\ ${ }^{2}$ Department of Electrical Engineering \\ King Saud University \\ Riyadh, Saudi Arabia \\ e-mail: essam@ksu.edu.sa \\ ${ }^{3}$ Saudi Electricity Company \\ Riyadh, Saudi Arabia \\ e-mail: eng.abdullah99@gmail.com
}

\begin{abstract}
PV power plants have been built the world over, and successfully proven as one of the important substitutes of alternative energy. Nowadays, there has been some series of movements in Saudi Arabia to find out solutions. This research aims to study the feasibility of design and construction of solar power plant using photovoltaic cells in Saudi Arabia from the geographic, economic and technical perspective.
\end{abstract}

\section{Key words}

Feasibility, Saudi Arabia, Study, PV.

\section{Introduction}

Kingdom of Saudi Arabia (KSA) is an Arabian country and the largest in the Peninsula. It is bordered by Jordan on the northwest, Iraq on the north and northeast, Kuwait, Qatar, Bahrain, and the United Arab Emirates lie to the east, Oman on the southeast, and Yemen on the southern half. It has an estimated population of 27.6 million, with approximately 2,150,000 square kilometers of area [1].

Recently, Energy has eventually reached its peak due to the growth and population of the country. In order to meet the growing electricity demand, the Kingdom must increase the installed power capacity from $35 \mathrm{GW}$ in 2007 to more than $72 \mathrm{GW}$ by 2022 . This will require a massive investment-program [1]. While the others are moving towards the conventional generation of power by heavy or light fuel or natural gas to meet this goal, this paper aims primarily to discuss the potential of applying PV technology to generate power for the Kingdom from geographic, economic and technical aspect.

It maybe a point to wonder why, the subject of production of electrical power through renewable energies, such as solar energy arises at a time when KSA has a huge reserve of oil and gas in the world. The main motivation as to why renewable energy is given much attention is because of its contribution to reduce harmful emissions to the environment, especially carbon dioxide.
There are rising concerns around the globe over the high oil and gas prices because of growing demand as well as the aspect to reserve oil for the next generation. Some isolated regions in KSA can be reached via RE technology too [2-8]. Hence, it is a great necessity to study the overview feasibility study of having PV power plants to generate electricity in Saudi Arabia.

\section{Overview of KSA power demand growth}

According to Fig. 1, in order to meet the growing electricity demand, the Kingdom must increase the installed power capacity from $35 \mathrm{GW}$ in 2007 to more than 72 GW by 2022 . The average electricity demand will grow from $22 \mathrm{MW}$ to almost $48 \mathrm{MW}$ at the end of this period. This will require a massive investment-program. While at the same time the difference between the average and the peak demand grows from $13 \mathrm{MW}$ to $25 \mathrm{MW}[1,9]$.

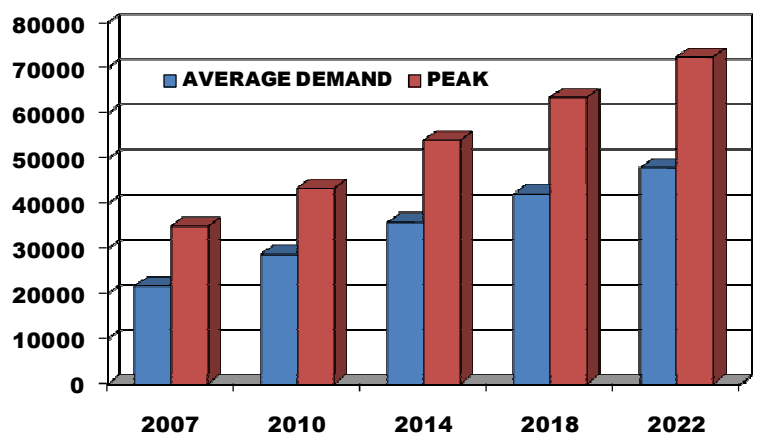

Fig. 1. KSA power demand growth in MW [9]

This increase in power demand results in a dramatic rise in the fuel required for utilities. The latest outlook requires a provision of oil equivalent about 2.8 million barrels/day by 2022, as shown in Fig. 2. This represents an almost $100 \%$ increase from current levels. The use of 
diesel for power generation is also increasing to cover the rising demand and generation in remote locations, as shown in Fig. 3.

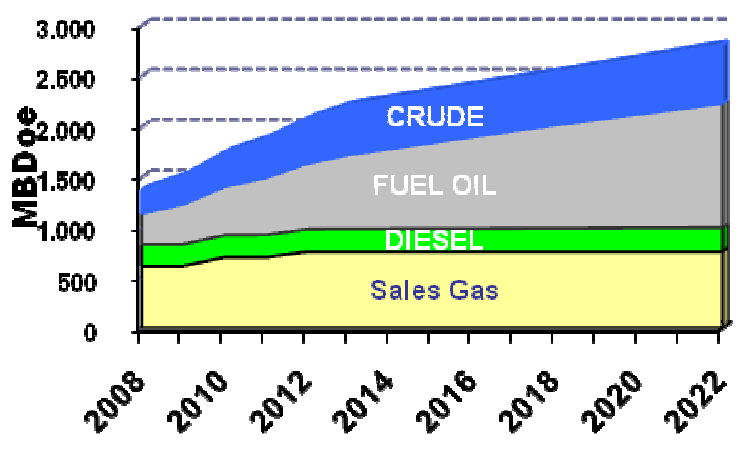

Fig. 2. Total fuel Demand for Utility [10]

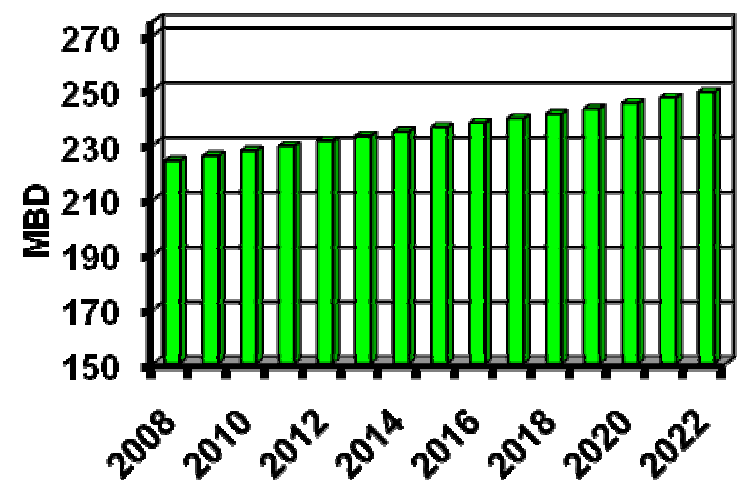

Fig. 3. Diesel Demand for power [10]

\section{Geographical viewpoint}

The successful use of solar cells to generate electric power by building a solar plant depends on several factors. The most important of factors is a 'geographic location'. To determine a good geographical point many things have to be kept in mind, the most important being the intensity of solar radiation, the longitude and the width and height lines above the sea level, where the strength of solar radiation has the primary role in determining whether possible construction of a solar panel is to be done or not.

The solar radiation at the surface of the Earth is about 1000 watt $/ \mathrm{m}^{2}[1,11]$, if the annual rate of the distribution of solar radiation per watt per square meter (watt $/ \mathrm{m}^{2}$ ) is taken for the entire world. It is noted that the Arab states are the best areas to take advantage of solar energy, including Saudi Arabia. In Europe, most countries in North America, most Latin American countries, and the countries of Western Asia, the annual rate of solar radiation is between $(100-200) \mathrm{watt} / \mathrm{m}^{2}$, while in the Arab countries, including the Gulf countries, it reaches to about $250 \mathrm{watt} / \mathrm{m}^{2}$. The intensity of solar energy on the Earth during its orbit around the sun, the Arab countries are to be found on a great deal for provision of this energy every day [11].
Fig. 5 shows the distribution of solar radiation for all regions in Saudi Arabia. It is be noted that the countries located in the south-west of Saudi Arabia receive a greater amount of solar radiation than the rest of the Kingdom, Therefore, we will introduce later on, the distribution of solar radiation in detail in all areas of the Kingdom.

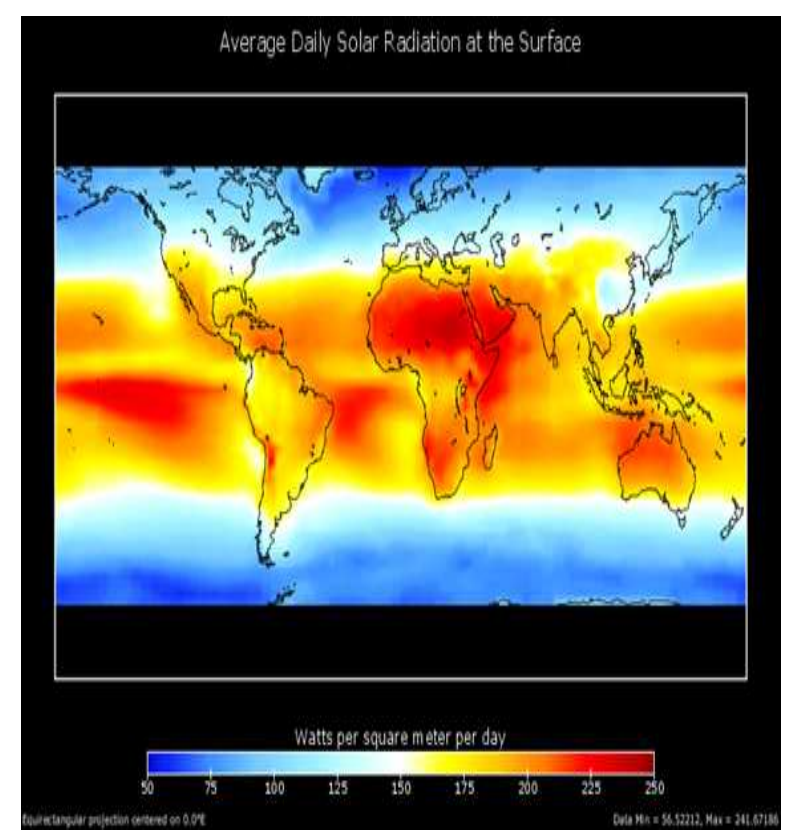

Fig. 4. The amount of solar radiation reaching the ground [11]

For comparison among all regions in Saudi Arabia, Fig. 6 shows how the solar radiation rate is extended throughout the year.

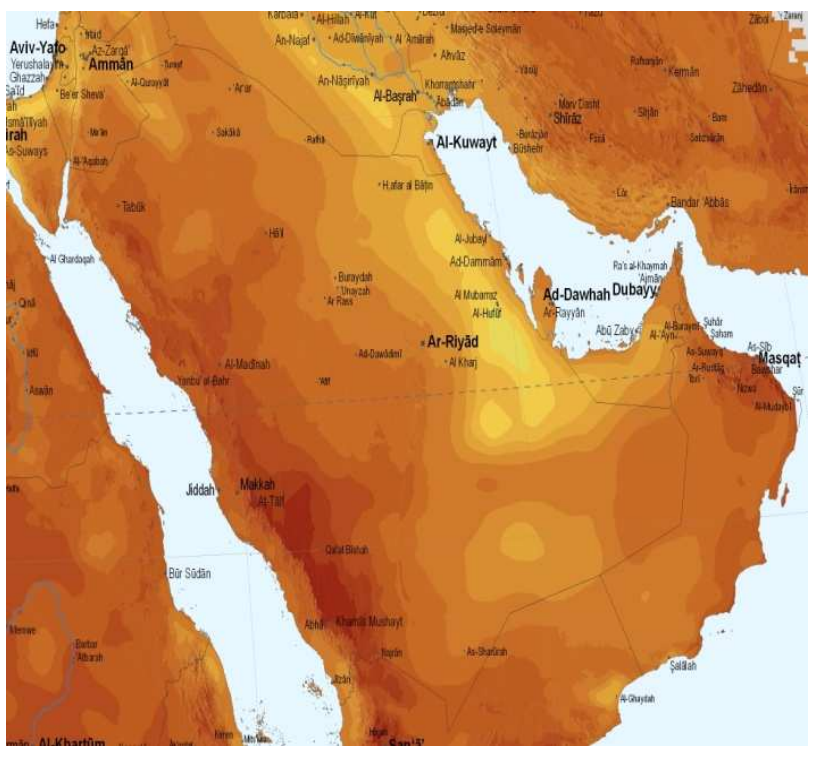

Fig. 5. The distribution of solar radiation in Saudi Arabia and neighboring countries [11]

As expected, the solar radiation in some months is less intense in most regions. The radiation is given in Mega Joules $/ \mathrm{m}^{2}$ for eight hours. 


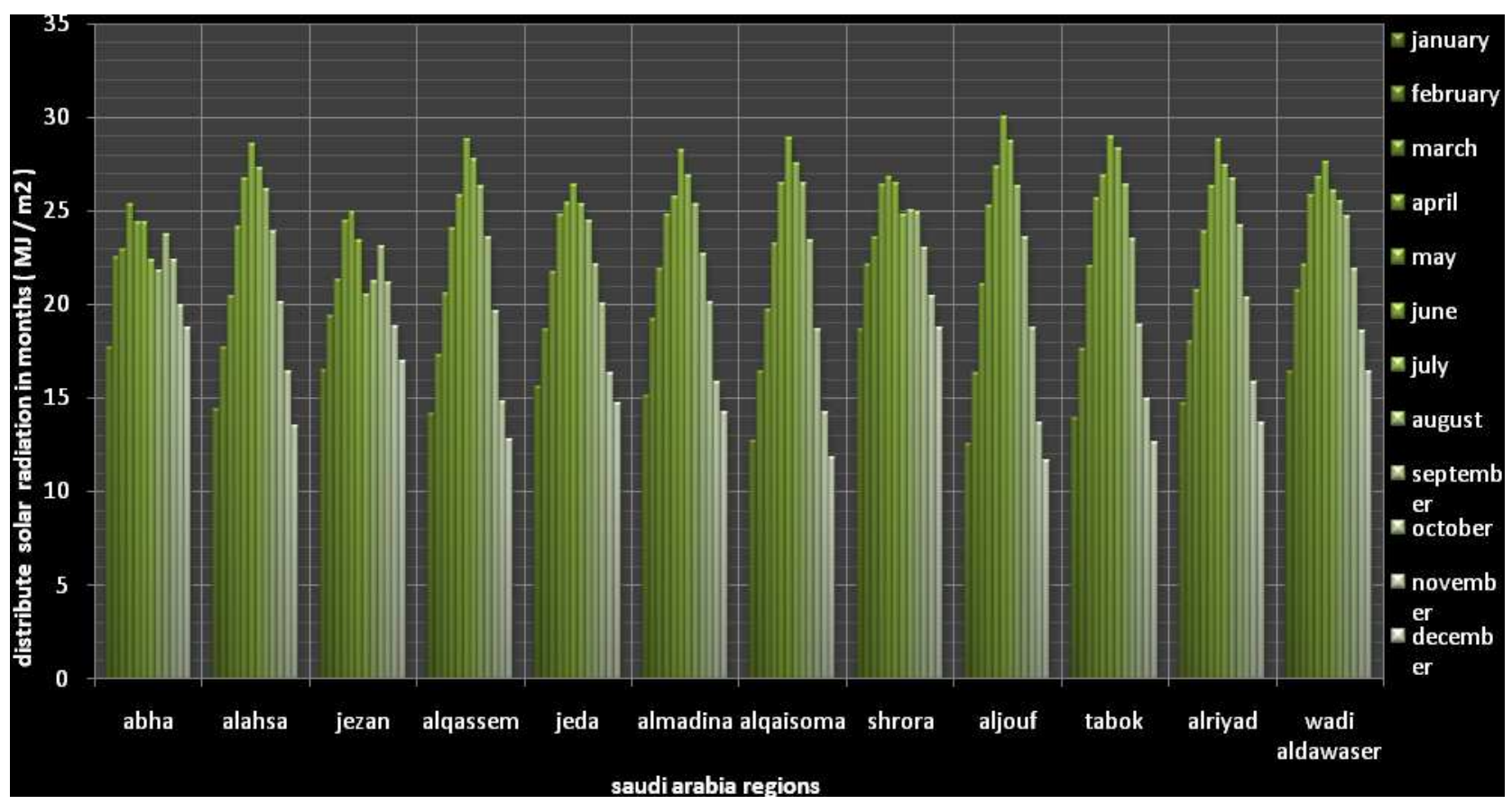

Fig. 6. Comparison of the solar radiation distribution to all parts of the Kingdom

\section{Economical viewpoint}

Here, a solar economic side will also be studied, where most important factors contributing to the construction of the station will be illustrated in detail. If the power plant's area is estimated about $1.25 \mathrm{~km}$, which means it will generate about $200-300 \mathrm{GW} / \mathrm{h} /$ year, save 500,000 barrels of oil a year, and avoid 200,000 tons of carbon dioxide per year [12].

Economical factors have an essential role in the calculation of the cost of solar plants, as well as revenue or profit, after operating the station.

1. The total cost of the station (total cost): Costs include all the requirements for the construction of a solar power plant.

2. Operation and maintenance costs (Operating and Maintenance Costs): These costs include the costs of operating the station from the wages of labor and the maintenance costs. The solar plants' maintenance is very low compared to other renewable energies and conventional energies.

3. Mandated fuel (fuel cost): Conventional energy in the amount of energy generated depends on the amount of fuel, but in this case, the fuel is sunlight, so there is no cost of fuel, which is a characteristic of solar energy i.e. its free of charge.

4. The cost of the sale of renewable energy (feedin tariff): any sale price per kilowatt per hour $(\$ / \mathrm{kW} / \mathrm{h})$, which is a return to the investor. Note that the tariff in $\mathrm{KSA}$ is $0.013 \$ / \mathrm{kW} / \mathrm{h}$ [8].
The annual total cost of the station can be calculated through the following law [13]:

$\mathrm{C}_{\mathrm{A}}=\frac{\mathrm{I}+\mathrm{D}+\mathrm{T}}{100} \mathrm{C}_{\mathrm{T}}+(\mathrm{O}+\mathrm{M}+\mathrm{R})+\mathrm{C}_{\mathrm{F}}$

Where,

$\mathrm{C}_{\mathrm{A}} \quad=$ Total annual cost

I $=$ Interest

$\mathrm{D} \quad=$ Decay

$\mathrm{T} \quad=$ Tax

$\mathrm{C}_{\mathrm{T}} \quad=$ Cost of building the station (total cost)

$\mathrm{O}+\mathrm{M}=$ Cost of operation and maintenance

$\mathrm{R}=$ Other costs

$\mathrm{C}_{\mathrm{F}} \quad=$ Cost of fuel

\section{A. Estimated prices of solar plants}

With regard to the prices of solar plants, the information based on prices was adopted from big companies that have a standard to build it. For the construction of a solar (Photovoltaic's Plant) with a capacity of $20 \mathrm{MW}$, Table I shows the total cost of the solar station and the cost of operation and maintenance.

Table I: Total cost and the cost of operation and mainten-

\begin{tabular}{|c|c|}
\multicolumn{2}{|c|}{ ance $(20 \mathrm{MW})$} \\
\hline Cost kind & Cost in dollars \\
\hline $\begin{array}{c}\text { Total cost of solar energy } \\
\text { ance, } 5 \% \text { of the total cost. }\end{array}$ & $3,954,058 \$$ \\
\hline
\end{tabular}


Energy emerging from the power adapter (inverter) DC = 19.99 MW.

Energy emerging from the power adapter (inverter) $\mathrm{AC}=$ 19.09 MW.

The efficiency of the power adapter $=97.6 \%$.

Energy per year (annual energy) $=33.039 \mathrm{GWh}$.

For the construction of a solar (Photovoltaic's Plant) with a capacity of $50 \mathrm{MW}$, Table II shows the total cost of the solar station and the cost of operation and maintenance.

Table II : The total cost and the cost of operation and maintenance (50 MW)

\begin{tabular}{|c|c|}
\hline Cost kind & Cost in dollars \\
\hline Total cost of solar energy & $199,746,793 \$$ \\
\hline $\begin{array}{c}\text { Operation cost and mainten- } \\
\text { ance, } 5 \% \text { of the total cost }\end{array}$ & $9,987,339 \$$ \\
\hline
\end{tabular}

Energy emerging from the power adapter (inverter) $\mathrm{DC}=$ 49.98 MW.

Energy emerging from the power adapter (inverter) $\mathrm{AC}=$ 48.23 MW.

The efficiency of the power adapter $=97.6 \%$.

Energy per year (annual energy) $=83.454 \mathrm{GWh}$.

For the construction of a solar (Photovoltaic's Plant) with a capacity of $100 \mathrm{MW}$, Table III shows the total cost of the solar station and the cost of operation and maintenance.

Table III : The total cost and the cost of operation and maintenance (100 MW)

\begin{tabular}{|c|c|}
\hline Cost kind & Cost per dollars \\
\hline Total cost of solar energy & $399,536,257 \$$ \\
\hline $\begin{array}{c}\text { Operation cost and main- } \\
\text { tenance, 5\% of the total } \\
\text { cost }\end{array}$ & $19,976,812 \$$ \\
\hline
\end{tabular}

Energy emerging from the power adapter (inverter) DC = 99.98 MW.

Energy emerging from the power adapter (inverter) $\mathrm{AC}=$ 96.48 MW.

The efficiency of the power adapter $=97.6 \%$.

Energy per year (annual energy) $=166.9 \mathrm{GW} / \mathrm{h}$.

\section{B. Feed-in-Tariff}

To build a solar plant using solar cells, there are some economical factors that must be taken into account, including tariff nutrition (feed-in tariff), and the tariff nutrition differ from one country to another. Standard feed-intariff will include a commitment by the company that generates electric power system to the government or the Ministry of Water and Electricity (MOWE) or entity's responsibility in determining the tariff of electricity.

The tariff of solar energy drops each year with respect to the previous one due to technical developments in solar cells, increasing number of manufacturers of solar cells, and intensity of competition between the manufacturers to launch their products at a lower price. All these factors have helped to lower Electricity cost of solar cells.

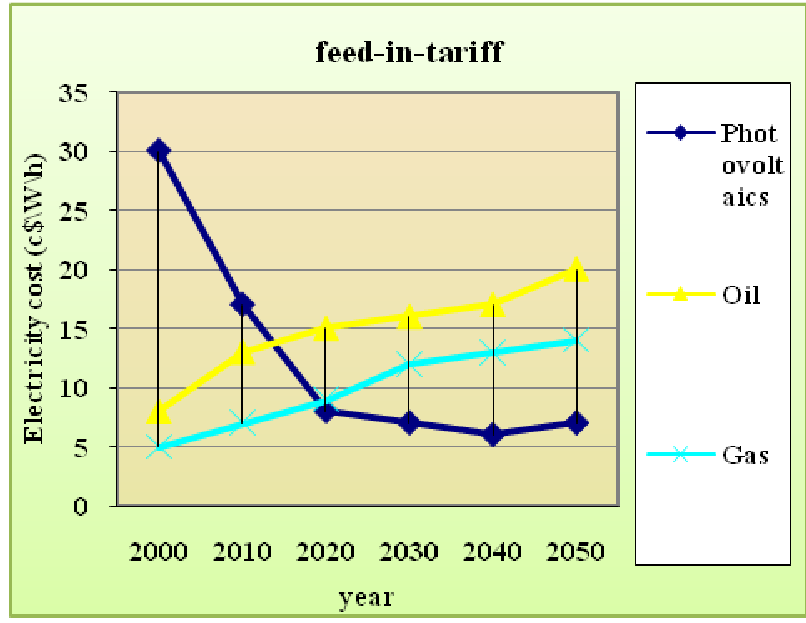

Fig. 7. Comparison of the feed-in-tarrif to identify the electricity of the solar cells and oil [14]

Feed-in-tariff system varies between $(0.2-0.3)$ $\$ / \mathrm{kW} / \mathrm{h}$ for power solar cells in the world. The energy tariff of solar cells was very high compared with the energy tariff of the oil. With the development of technologies of solar cells, prices of electricity have been significantly reduced over time. It is expected that the decline in tariffs is still ongoing until it reaches the break-even point with the oil tariff, as shown in Fig. 7, which notes the break-even point for solar power against oil in the tariff in the year 2015 [13].

To calculate feed-in-tariff, the station costs should be calculated annually as mentioned before by using the equation then dividing them on the annually output power. Suppose that the taxes and benefits are deleted in order to support building and spreading of solar station. The age of the solar station is usually from 20 to 25 years.

Annual solar station cost $=$

(Total cost of the solar station / Age of the solar station)

+ Working and maintenance costs

For example, the station produces $20 \mathrm{MW}$, and assuming its age is 25 years, then annual solar station cost will be 7.1 million dollars, and feed-in tariff will be 0.21 $\$ / \mathrm{kW} / \mathrm{h}$. If the age of the solar station is assumed to be 20 years, then the annual solar station cost will be 7.9 million dollars, and feed-in-tariff will be $0.24 \$ / \mathrm{kW} / \mathrm{h}$. The calculating tariff represents the generating part only, as the tariff of transporting and distribution represents $30 \%$ of generating tariff [1].

\section{Technical viewpoint}

\section{A. Using specialized programs}

Specialized programs to simulate PV power plants are to be used. One of these programs is PVSYST and SUNNY design. By using these programs, we can know all the devices that had been used in accounting the costs of the solar station, as all the devices that are used in the 
solar stations by all its kinds from different global companies are included in the program. The changes that happen to the station will be included in the program like the amount of the solar rays. The temperature, wind speed, station location according to Meridians and Latitude, station height according to sea level, and time are specified. Solar rays curve in a daily, monthly, and annually manner and so the power in a daily, monthly, and annually manner can be produced accordingly [1].

Peak loads in KSA occur around at noon in which consumption of the electric power reaches high level in comparison with other periods of the day. This is a very important factor in using solar power. The actual peak load in Saudi Arabia happens in between 11:00AM to 3:00PM [1] in summer time. As mentioned previously in Figs. 1and 3, the increasing demand of electricity in KSA is noted. The load reaches highest in peak hours. This amount is very big, but using solar power in this time will help in feeding the loads with electricity.

\section{B. Site location}

The site location has been chosen to build the solar station in Riyadh, which has a high rate radiation especially in rush hour. Fig. 8 represents the amount of solar radiation in Riyadh area [1].

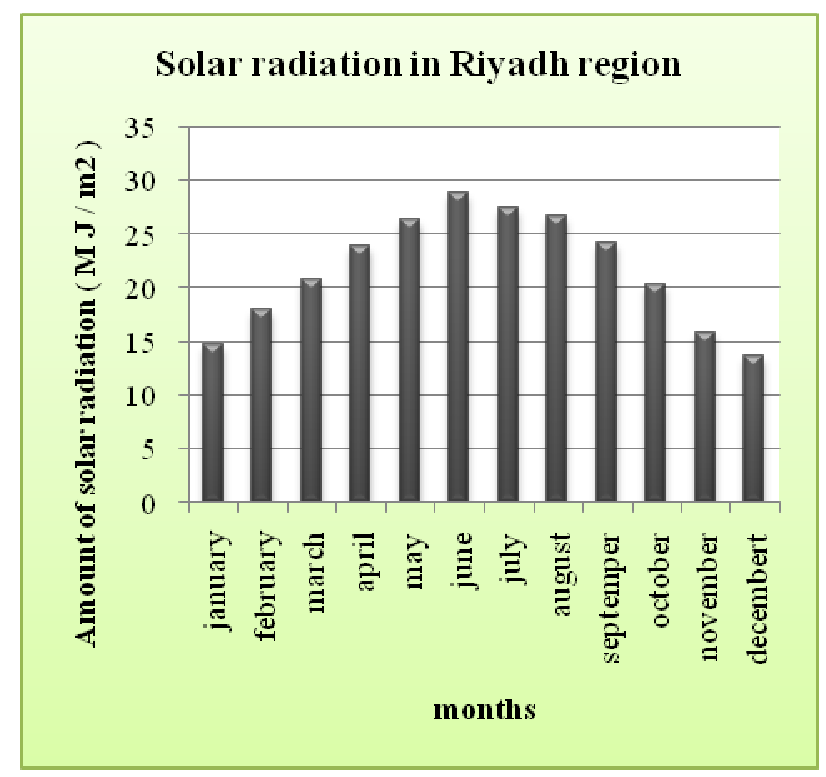

Fig. 8. Solar radiation in Riyadh region

The generated power from the solar station depends totally on the amount of solar rays. The amount of solar rays considers the beginning-time of rays, end-time of rays, and the amount of rays when the sky is clear and when it becomes cloudy. Fig. 9 shows the solar rays in Riyadh on the daily basis. Solar rays starts from 6:00 AM to 5:00 PM. Note the difference between the day when the sky is clear and the day when the sky is partially cloudy [15]. For this reason, southern areas in KSA, like Abha area cannot be chosen, as it experiences clouds and rain. In addition, Riyadh region has a high electricity load in peak hours than in other areas [1].
Riyadh

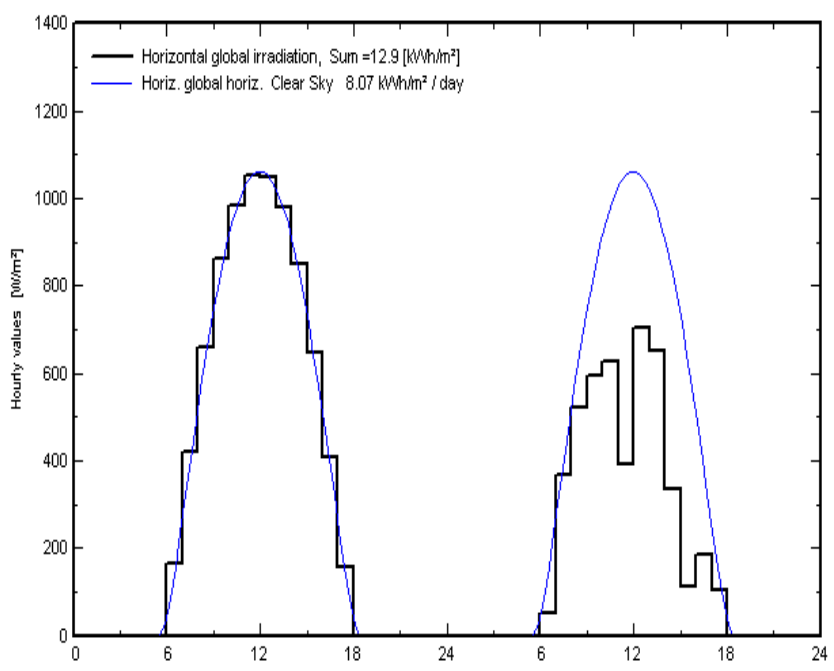

Fig. 9. Solar radiation in Riyadh region

\section{Power plant specifications}

Followings are the Power plant specifications:

The required (area) $=344.222 \mathrm{~km}^{2}$ nearly $587 \mathrm{~m}$ (length) and $587 \mathrm{~m}$ (width). The power generated from the (inverter) $\mathrm{AC}=48234 \mathrm{KW}=48.23 \mathrm{MW}$. Annual energy $=83.45$ $\mathrm{GW} / \mathrm{h}$. The number of Solar panels that are connected in series $=15$ solar panels. The number of solar panels that are connected in Parallel $=14032$ Solar panels. So the total number of the Solar panels in the station $=210480$ solar panels. The number of the used inverters $=4385$ inverters. The Voltage of the station $=390 \mathrm{~V}$. Open circuit Voltage $\left(\mathrm{V}_{\mathrm{oc}}\right)=618 \mathrm{~V}$. The output Current $=11.66$ kA. Short circuit current $\left(\mathrm{I}_{\mathrm{sc}}\right)=23.35 \mathrm{kA}$.

Fig. 10 represents the output power of the station in a monthly manner and the total power of the year equals $83.45 \mathrm{GW} / \mathrm{h}$.

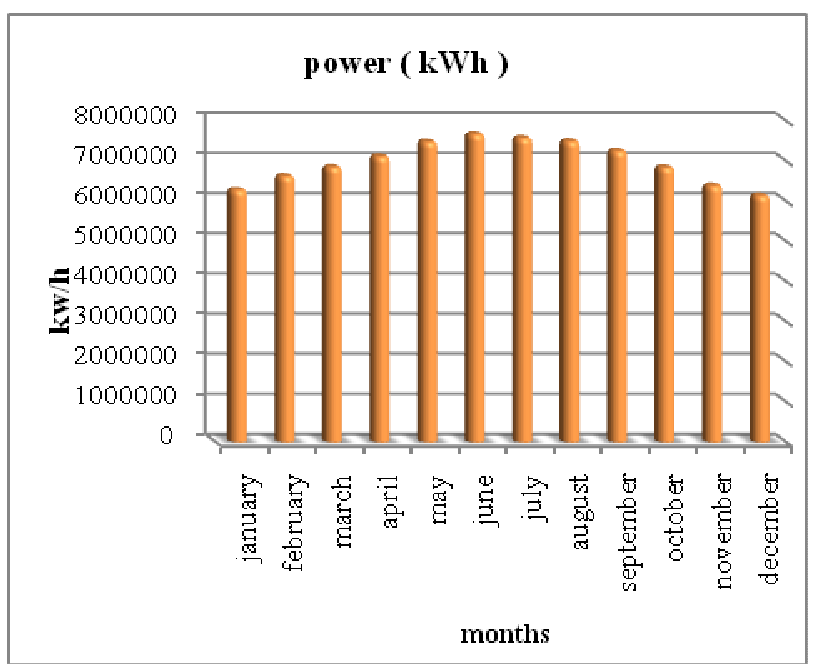

Fig. 10. The output power of the PV power plant

Fig. 11 represents the output power of the solar station in two different days. In the first day, the output power was very high, but in the second day, the output power was lower as the sky was partially cloudy. The output power in the first day is $278605 \mathrm{~kW} / \mathrm{h}$ while the 
output power in the second day is $1623910 \mathrm{~kW} / \mathrm{h}$. The average of the output power in the two days is 220498 $\mathrm{kW} / \mathrm{h}$. Fig. 12 shows the output power in November month for every day. It is noticed that there are some days in which the output power is very low in comparison with the other days, when the sky is cloudy as mentioned previously. The output power from the PV power plant is directly connected to the grid, whether directly with the inverter without using a step up transformer, or by the connection with the grid via step up transformer. It is suggested that the location of PV power plant is installed by using step up transformer, through transmission line $13.8 \mathrm{kV}$.

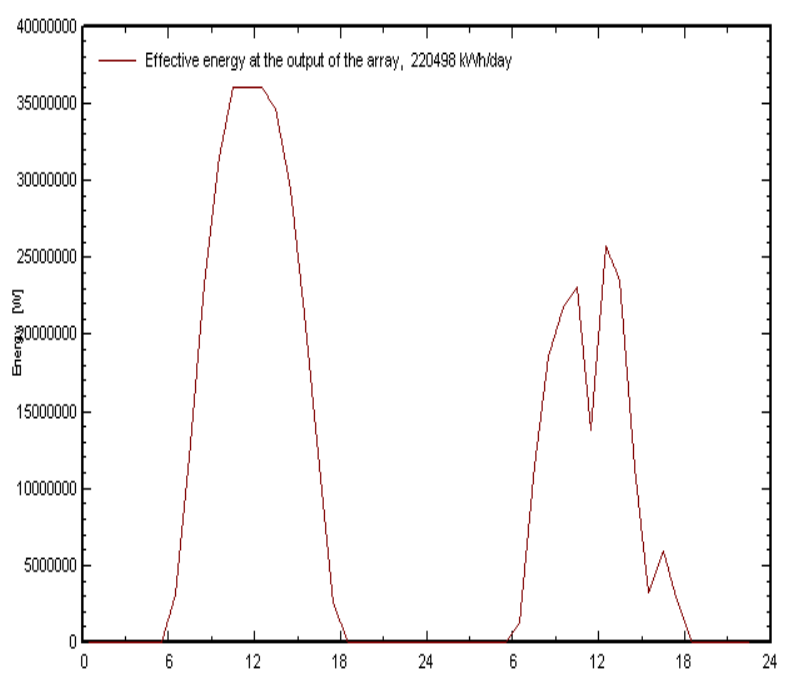

Fig. 11. The output power from the solar station in two different days

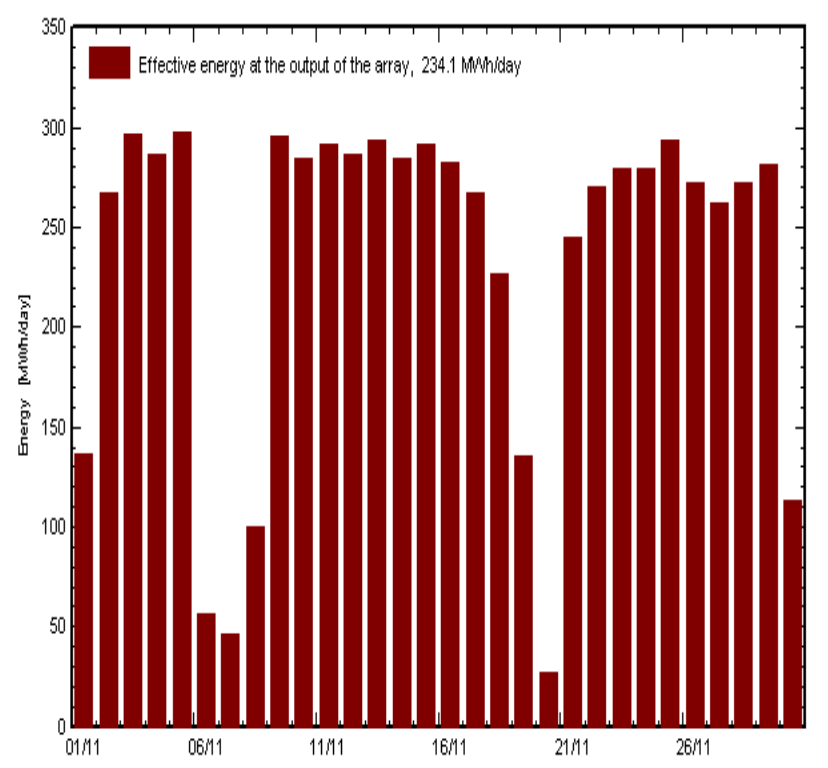

Fig. 12 The output power in November every day

\section{Conclusion}

Enormous amounts of solar radiation are located in KSA without utilizing the solar energy. The calculated tariff of the solar station ranges from 0.216 to 0.24 $\$ / \mathrm{kW} / \mathrm{h}$, and this tariff is responsible, as PV tariff nowadays ranges from 0.2 to $0.3 \$ / \mathrm{kW} / \mathrm{h}$. Nevertheless, this tariff is enormous compared to the traditional power in KSA. The PV tariff used in some countries is supported by the government (subsidy tariff), or through energy procurement process. It is anticipated that integrating both methods will be the appropriate solution in the Kingdom.

To summarize, the Kingdom's electricity demand will double in the next 15 years, dramatically increasing liquid fuel consumption. According to this preliminary analysis, PV power is competitive with the conventional capacity required to meet "peak" power demand and represent an opportunity for reducing fuel consumption.

\section{References}

[1] E. Al-Ammar and A. Al-Aotaibi, "Feasibility study of establishing a PV power plant to generate electricity in Saudi Arabia, from technical, geographical, and economical viewpoints," Technical report, written in Arabic language, July 2009.

[2] T. Markvart, "Solar Electricity," Johan Wiley \& Sons, ltd , Chichester, UK, 1995.

[3] L. Freris and D.Infield, "Renewable energy in power system," 1 st edition, Johan Wiley \& Sons, ltd, Publication, UK, 2008.

[4] C. S. Solanki, "Renewable energy technologies: A practical guide for beginners," Prentice-Hall, India, 2008. [5] "Sustainable Energy Systems," Technical report on Energy Efficient and Renewable Energy Systems Planning and Recommendations for their Successful Application, IEEE power engineering society, 2006, pp. 33-57.

[6] R. L. Laverley, "Electrical supply and demand in sierra leone and the potential of photovoltaic's," Dalhousie University, Canada, 1998

[7] German Solar Energy Society (DGS), "Planning and installing photovoltaic system," 2nd edition, 2005.

[8] S. Duggirala and Z. Li, "Case Studies on the Economic Viability of Renewable Energy" IEEE power engineering society, 2006.

[9] Presentation slides and technical reports, Saudi Electricity Company (SEC), 2009.

[10] Presentation slides and technical report, Saudi ARAMCO, 2009.

[11] Energy Research Institute, "Kingdom of Saudi Arabia solar radiation atlas," Technical report, King Abdulaziz city for science and technology (KACST), Riyadh, Saudi Arabia, 1998.

[12] J. A. White, K. E. Case, Davio B. Pratt and M. H. Agee, "Principles of Engineering Economic Analysis," 4th edition, John Wiley \& Sons Inc., 1998.

[13] Independent Competition and Regulatory Commission (ICRC), "Feed-In Tariff Discussion Paper - Comments," Discussion paper, 2008.

[13] Jenergy technologies company, "Solar-Electric Design Guide," Report, 2002, pp. 2-36.

[14] European Photovoltaic Industry Association, "European pv associations' position paper on a feed-in tariff for photovoltaic solar electricity," reports, 2005, Available at: www.epia.org

[15] D. Lenardič, "Large-Scale Photovoltaic Power Plants Cumulative and Annual Installed Power Output Capacity," Annual review, 2008, Available at: http://www.pvresources.com/download/AnnualReview_F reeEdition.pdf. 